\title{
Uji Antibakteri Rhizopus sp. Asal Inokulum Tempe terhadap Vibrio cholerae
}

\section{Antibacterial Test of Rhizopus sp. from Tempeh Inoculum Against Vibrio cholerae}

\author{
Nur Khikmah* dan Apriani Shayoti Haloho² \\ ${ }^{1}$ Akademi Analis Kesehatan Manggala Yogyakarta, Indonesia \\ ${ }^{2}$ Rumah Sakit Samarinda Citra Medika, Samarinda, Kalimantan Timur, Indonesia
}

\begin{abstract}
Abstrak
Rhizopus sp. merupakan kapang yang digunakan dalam fermentasi tempe. Kapang Rhizopus pada tempe telah dikaji manfaatnya dalam mengurangi kejadian diare pada Escherichia coli dan Salmonella typhi dibandingkan pada Vibrio cholerae. Diare kolera yang disebabkan oleh Vibrio cholerae pernah menjadi Kejadian Luar Biasa (KLB) di Indonesia, sehingga bakteri kolera sebagai penyebab penyakit pada penderita diare masih ada. Penelitian ini bertujuan untuk mengetahui kemampuan antibakteri Rhizopus sp asal inokulum tempe terhadap Vibrio cholerae dan mengetahui perbedaan kemampuan antibakteri Rhizopus sp dari beberapa inokulum tempe terhadap Vibrio cholerae. Uji antibakteri Rhizopus sp terhadap Vibrio cholerae dilakukan dengan metode difusi kertas. Isolasi dari inokulum tempe komersial memperoleh dua isolat kapang, yang teridentifikasi Rhizopus sp.IP dan Rhizopus sp. IJ. Hasil uji antibakteri menunjukkan bahwa dua isolat Rhizopus sp. tersebut dapat menghambat Vibrio cholerae. dengan kemampuan penghambat kategori sedang dan tidak terdapat perbedaan aktivitas antibakteri Rhizopus sp. IP dan Rhizopus sp. IJ terhadap Vibrio cholerae.
\end{abstract}

Kata kunci : Rhizopus sp. antibakteri, tempe, Vibrio cholerae

\begin{abstract}
Rhizopus sp. is a common mold used in fermenting tempeh. Rhizopus sp in tempeh has been studied for its benefits in reducing the incidence of diarrhea caused by Escherichia coli and Salmonella typhi compared to Vibrio cholerae. Cholera diarrhea caused by Vibrio cholerae was an outbreak in Indonesia and the presence of choleral bacteria as causal agent of diarrhea is still exists until now. This research aims were to determine the antibacterial activity of Rhizopus sp. from tempeh inocula against Vibrio cholerae and to study the differences of selected Rhizopus sp. inocula antibacterial activity against Vibrio cholerae. Disc diffusion method was employed to test antibacterial activity of Rhizopus sp. on Vibrio cholerae. Isolation of Rhizopus sp. from commercial tempeh inocula obtained two mold namely Rhizopus sp. IP and Rhizopus sp. IJ. The results showed that Rhizopus sp. from commercial tempeh inoculum was able to inhibit Vibrio cholerae. The inhibitory ability was groupped in the medium inhibition category and no difference observed in antibacterial activity of Rhizopus sp. IP and Rhizopus sp. IJ against Vibrio cholerae.
\end{abstract}

Keywords : Rhizopus sp., antibacterial, tempeh, Vibrio cholerae

\footnotetext{
* Corresponding author:

Nur Khikmah

Akademi Analis Kesehatan Manggala Yogyakarta

Jl. Bratajaya No. 25, Sokowaten, Banguntapan, Bantul

E-mail: khikmahnr@gmail.com
} 


\section{Pendahuluan}

Rhizopus merupakan kelompok kapang yang digunakan sebagai inokulum dalam pembuatan tempe. Masyarakat umumnya menyebut inokulum tempe dengan nama laru atau ragi tempe. Spesies Rhizopus yang digunakan sebagai inokulum tempe bermacam-macam. Hasil isolasi dan identifikasi kapang dari tempe dan ragi tempe menghasilkan spesies Rhizopus yang berbeda-beda, diantaranya Rhizopus oligosporus, Rhizopus oryzae, Rhizopus cohnii (Purwijantiningsih et al., 2005), Rhizopus oligosporus (Dewi \& Aziz, 2011), dan Rhizopus microsporus (Hartanti et al., 2015).

Pada pembuatan tempe, Rhizopus berperan sebagai pengepak butiran kedelai menjadi bentuk padat dengan anyaman miselium. Rhizopus juga berperan dalam proses enzimatik yang mengubah senyawa kompleks menjadi senyawa sederhana sehingga mudah diserap oleh tubuh. Dengan adanya proses tersebut, maka tempe mengandung semua asam amino esensial, kalsium, asam lemak, vitamin, dan isoflavon (Babu et al., 2009).

Pada awal tahun 1960, tempe telah dilaporkan mengandung zat antibakteri (Nout \& Kiers, 2005). Masyarakat secara empiris telah mengetahui bahwa tempe dapat dijadikan makanan yang membantu proses penyembuhan diare. Saat diare, konsistensi feses menjadi lembek atau cair dan frekuensi buang air besar menjadi lebih sering dalam satu hari. Menurut Brooks et al. (2012), diare dapat disebabkan oleh infeksi bakteri Eschericia coli, Salmonella typhi, Shigella dysenteriae, dan Vibrio cholerae. Babu et al. (2009) melaporkan penelitian yang menyatakan bahwa orang Indonesia yang mengonsumsi tempe secara rutin akan terhindar dari penyakit disentri dan gangguan pencernaan.

Karmini et al. (1987) melaporkan bahwa tempe mempunyai pengaruh dalam mengurangi resiko terhadap diare akibat infeksi bakteri enteropatogenik Escherichia coli 0125K70 (B)H19. Kiers et al. (2003), juga membuktikan kacang kedelai yang difermentasi dengan Rhizopus dapat mengurangi keparahan diare pada anak babi yang disebabkan oleh Enterotoxigenic
Escherichia coli (ETEC) K88 dibandingkan dengan kacang kedelai panggang.

Senyawa metabolit Rhizopus oligosporus NRRL 2710 menunjukkan aktivitas penghambatan terhadap patogen yang diuji. Urutan penghambatan tertinggi pada Eschericia coli dan Salmonella typhi, diikuti Pseudomonas aeruginosa, kemudian Staphylococcus aureus, Corynebacteria diphtheriae dan Klebsiella pneumoniae (Fadahunsi et al., 2013).

Kajian pengaruh tempe ataupun kapang tempe (Rhizopus) dalam mengurangi kejadian diare sampai saat ini banyak dilakukan pada E. coli dan S. typhi sebagai bakteri penyebab dibandingkan pada $V$. cholerae. Brooks et al. (2012) menyatakan bahwa diare yang disebabkan oleh $V$. cholerae dikenal dengan nama penyakit kolera. Gejala khas diare kolera teramati pada bentuk dan warna tinja seperti air cucian beras, mengandung mukus dan sel epitel. Menurut Puspandari et al. (2009), Kejadian Luar Biasa (KLB) kolera yang pernah dilaporkan di Indonesia tercatat terjadi pada bulan April hingga Agustus 2008 di Kabupaten Paniai dan Kabupaten Nabire, Provinsi Papua. Kejadian ini menelan korban 105jiwa. Setelah itu, tidak didapatkan laporan terbaru mengenai jumlah kasus kolera di Indonesia hingga saat ini.

Sariadji (2019) menuliskan bahwa dalam laporan terakhir periode 2017-2018, WHO melaporkan tidak terdapat kasus kolera di Indonesia. Data WHO merujuk pada data resmi Kementerian Kesehatan Republik Indonesia. Namun data kasus kolera di Indonesia tidak terlapor secara kumulatif di pusat data dan informasi kesehatan Kementerian Kesehatan RI. Data yang tersedia saat ini di Indonesia adalah data diare yang bersifat umum. Diare yang terdata tersebut disebabkan oleh banyak hal dan tidak spesifik, didasarkan pada gejala klinis atau keterangan melalui proses wawancara tanpa penunjang diagnostik laboratorium. Oleh karena kolera pernah terjadi di Indonesia, maka keberadaan bakteri Vibrio cholerae sebagai penyebab diare penderita diare diduga masih ada, akan selalu ada, dan potensial mengancam wilayah di Indonesia ketika faktor risiko kejadian 
kolera terpenuhi. Faktor risiko kolera masih terdapat di Indonesia karena indikator Perilaku Hidup Bersih dan Sehat (PHBS) di Indonesia masih rendah (32,3\%). Tingkat indikator PHBS terendah di Indonesia terdapat di Papua dengan nilai 16,4\%.

Berdasarkan uraian tersebut, maka dilakukan penelitian tentang antibakteri Rhizopus sp asal inokulum tempe terhadap Vibrio cholerae, dengan tujuan untuk mengetahui kemampuan antibakteri Rhizopus sp. asal inokulum tempe dan mengetahui perbedaan kemampuan antibakteri Rhizopus sp. asal inokulum tempe yang berbeda terhadap Vibrio cholerae.

\section{Materi dan Metode \\ Persiapan Sampel}

Sampel yang digunakan adalah 2 inokulum tempe, yaitu merek Raprima (PT. Aneka Fermentasi Industri, Bandung) dan merek Jago Kate (UD. Jaya Mulya, Kediri). Bakteri Vibrio cholerae yang digunakan berasal dari Balai Laboratorium Kesehatan (BLK) Yogyakarta.

\section{Isolasi dan Identifikasi Rhizopus dari Inokulum Tempe}

Isolasi Rhizopus sp. dilakukan menggunakan metode spread plate. Sebanyak 1 gram inokulum tempe dilarutkan dalam

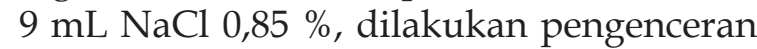
secara serial $10^{-1}$ sampai $10^{-3}$. Pada dua pengenceran terakhir, suspensi diinokulasi pada medium Potato Dextrose Agar (PDA) secara aseptis untuk kemudian diinkubasi selama 4 hari pada suhu kamar. Setelah inkubasi, dilihat pertumbuhan kapang, kemudian dilakukan pemurnian sampai isolat kapang benar-benar murni (Dewi \& Aziz, 2011). Isolat yang telah murni kemudian diidentifikasi berdasarkan pengamatan secara makroskopis dan mikroskopis mengacu pada pustaka Fundamentals of Diagnostic Mycology (Fisher \& Cook, 1998) dan Introduction to Food and Airborne Fungi (Samson et al., 2004).

\section{Produksi Antibakteri dari Rhizopus}

Isolat Rhizopus sp yang telah teridentifikasi diinokulasi kembali pada PDA dan diinkubasi selama 4 hari. Isolat tersebut kemudian digunakan untuk produksi zat antimikroba. Senyawa antibakteri diproduksi dengan cara fermentasi cair. Isolat Rhizopus sp. yang tumbuh diambil sebanyak 4 bulatan dengan perforator berdiameter $5 \mathrm{~mm}$, diinokulasi pada $20 \mathrm{~mL}$ Sabouraud Dextrose Broth (SDB), diinkubasi dalam shaker selama 6 hari dengan kecepatan 100 rotary per minute (rpm) pada suhu kamar. Hasil fermentasi disentrifugasi dengan kecepatan 3000 rpm selama 15 menit. Supernatan atau filtrat yang diperoleh digunakan untuk uji aktivitas antibakteri (Sukron et al., 2014).

\section{Uji Antibakteri Rhizopus pada Vibrio cholerae}

Uji antibakteri Rhizopus sp. pada Vibrio cholerae dilakukan menggunakan metode difusi kertas (disc diffusion). Blank disc dengan diameter $5 \mathrm{~mm}$ direndam dalam supernatan, lalu diletakkan di permukaan Nutrien Agar (NA) yang yang telah diinokulasi dengan $V$. cholerae. Kontrol positif yang digunakan adalah tetrasiklin $(30 \mu \mathrm{g})$ dan kontrol negatif berupa akuades steril. Media selanjutnya diinkubasi selama 24 jam pada suhu ruang. Kemampuan antibakteri ekstrak Rhizopus sp. terhadap $V$. cholerae ditunjukkan oleh keberadaan zona hambat di sekitar disc (Sukron et al., 2014). Kriteria daya antibakteri berdasarkan diameter zona hambat dikelompokkan menurut Davis \& Stout (1971).

\section{Hasil}

\section{Isolasi dan Identifikasi Rhizopus dari} Inokulum Tempe

Isolasi kapang dari 2 inokulum tempe mempeoleh 2 isolat (Tabel 1).

Tabel 1. Hasil isolasi kapang dari inokulum tempe

\begin{tabular}{lcc}
\hline $\begin{array}{c}\text { Merek Inokulum } \\
\text { Tempe }\end{array}$ & Jumlah Isolat & Kode Isolat \\
\hline Raprima & 1 & IP \\
Jago Kate & 1 & IJ \\
\hline Jumlah & 2 & \\
\hline
\end{tabular}

Pengamatan makroskopis dilakukan dengan mengamati koloni pada medium PDA menunjukkan bahwa kedua isolat berbentuk filamen, berteksur cottony, berwarna putih keabuan sampai hitam, miselium tumbuh 


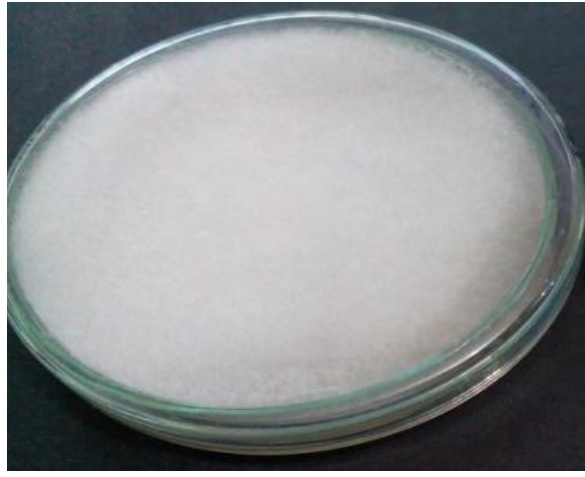

IP

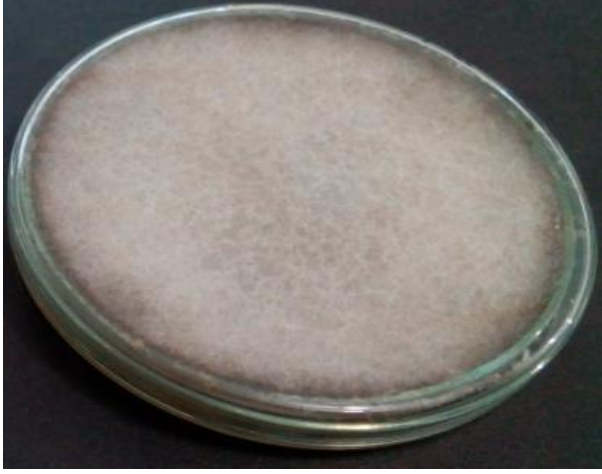

IJ

Gambar 1. Pertumbuhan isolat dari inokulum tempe : Raprima (IP) dan Jago Kate (IJ) pada medium PDA
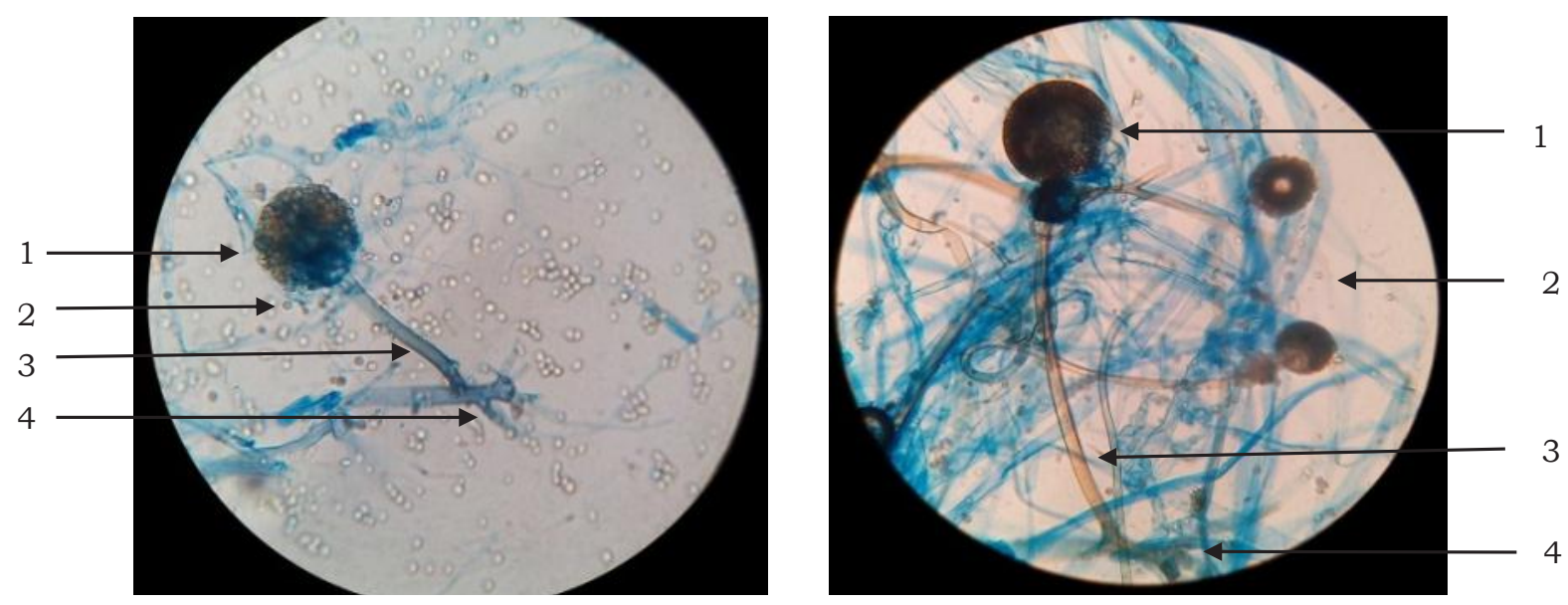

Gambar 2. Pengamatan mikroskopis isolat dari inokulum tempe : Raprima (IP) dan Jago Kate (IJ)

Keterangan : sporangium (1), sporangiospora (2), konidiofor (3), dan rizoid (4)

dengan cepat sehingga memenuhi cawan petri (Gambar 1).

Pengamatan secara mikroskopis isolat menunjukkan hifa hialin, tidak bersepta, dan terdapat hifa horizontal berupa stolon. Pada stolon muncul sporangiofor dan rizoid. Sporangofor tumbuh ke atas menyangga stuktur sporangium yang menghasilkan sporangiospora. Sporangiospora berbentuk bulat dan bewrana coklat kehitaman. Rizoid akan tumbuh ke dalam medium (Gambar 2).

Identifikasi isolat kapang dilakukan berdasarkan karakterisasi pada pengamatan makroskopis dan mikroskopis dengan mengacu pada Fundamentals of Diagnostic Mycology (Fisher \& Cook, 1998) dan Introduction to Food and Airborne Fungi (Samson et al., 2004). Berdasarkan karakterisasi tersebut, maka isolat kapang IP dan IJ teridentifikasi sebagai anggota Rhizopus dengan ciri adanya rizoid.

\section{Uji Antibakteri Rhizopus. pada Vibrio cholerae}

Uji antibakteri Rhizopus sp. dari dua merek inokulum tempe menunjukkan bahwa Rhizopus sp. mampu menghambat pertumbuhan Vibrio cholerae. Kemampuan penghambatan ditandai dengan terbentuknya zona hambat berupa zona jernih di sekitar disc (Gambar tidak ditunjukkan). Klasifikasi kriteria zona hambat dihitung berdasarkan diameternya. Hasil pengukuran diameter zona hambat pada masing-masing kelompok disajikan pada Tabel 1.

Diameter zona hambat dianalisis menggunakan uji-t untuk mengetahui perbedaan daya hambat Rhizopus sp. IP dan Rhizopus sp. IJ terhadap V. cholerae. Analisis uji-t antara Rhizopus sp. IP dan Rhizopus sp. IJ menghasilkan nilai signifikansi 0,889 pada taraf kepercayaan 95\% (Tabel 2). 
Tabel 1. Rata-rata diameter zona hambat Rhizopus pada pertumbuhan Vibrio cholerae

\begin{tabular}{lc}
\hline \multicolumn{1}{c}{ Ekstrak } & $\begin{array}{c}\text { Diameter zona } \\
\text { hambat }(\mathbf{m m})\end{array}$ \\
\hline Rhizopus IP & 9,25 \\
Rhizopus IJ & 9,38 \\
Tetrasiklin 30 $\mu \mathrm{g}($ kontrol +) & 21 \\
Akuades (kontrol -) & 0 \\
\hline
\end{tabular}

Tabel 2. Hasil uji-t antara Rhizopus IP dan Rhizopus IJ

\begin{tabular}{|c|c|c|c|}
\hline \multirow[b]{2}{*}{ Isolat } & \multicolumn{2}{|c|}{ Diameter (mm) } & \multirow[b]{2}{*}{ P value } \\
\hline & $\begin{array}{c}\text { Rhizopus } \\
\text { IP }\end{array}$ & $\begin{array}{l}\text { Rhizopus } \\
\text { IJ }\end{array}$ & \\
\hline Rhizopus & 9,25 & 9,38 & 0,889 \\
\hline
\end{tabular}

\section{Pembahasan}

\section{Isolasi dan Identifikasi Rhizopus dari Inokulum Tempe}

Dua isolat kapang IP dan IJ dari inokulum tempe komersial teridentifikasi sebagai anggota Rhizopus dengan ciri adanya rizoid. Pada penelitian ini identifikasi tidak dilakukan sampai spesies. Menurut Fisher \& Cook, (1998) dan Samson et al. (2004), koloni Rhizopus mempunyai ciri mampu tumbuh dengan cepat, hifa tidak bersepta, mempunyai stolon, rizoid dan sporangiofor. Sporangiofor dapat tunggal atau berkelompok, biasanya tidak bercabang. Sporangiofor menyangga sporangium yang banyak mengandung sporagiospora. Sporangium hialin menjadi coklat kehitaman dengan bertambahnya umur kultur. Kolumela berwarna coklat dan berbentuk globose. Sporangiospora berbentuk ovoid atau elips, berwarna coklat kehitaman.

Rhizopusspp.merupakanmikroorganisme utama dalam fermentasi tempe, yang sekarang umumnya berasal dari salah satu jenis laru komersial yang diproduksi secara pabrikan (Barus et al., 2019). Rhizopus dapat digunakan sebagai kultur tunggal dalam laru. Beberapa penelitian terdahulu mengidentifikasi kapang dari inokulum tempe komersial Raprima. Purwijantiningsih et al. (2005) yang mengisolasi kapang dari ragi tempe Raprima memperoleh isolat kapang tunggal yang teridentifikasi Rhizopus oligosporus.

Hasil tersebut sesuai dengan penelitian Hartanti et al. (2015), memperoleh 36 Rhizopus yang diisolasi dari tempe yang berasal dari 29 daerah di Indonesia. Hasil identifikasi menunjukkan 34 Rhizopus teridentifikasi sebagai Rhizopus microsporus var. oligosporus dan dua Rhizopus teridentifikasi sebagai $R$. delemar. Berdasarkan survei yang dilakukan, tempe yang diproduksi di Jawa dan Sumatera umumnya menggunakan ragi komersial Raprima. Ragi Raprima diproduksi di Bandung menggunakan R. microsporus var. oligosporus (sinonim $R$. microsporus) sebagai inokulum. Babu et al. (2009), menyatakan $R$. oligosporus mempunyai peranan utama dalam fermentasi tempe.

\section{Uji Antibakteri Rhizopus pada Vibrio cholerae}

Kemampuan antibakteri Rhizopus sp. terhadap $V$. cholerae dikarenakan selama fermentasi Rhizopus mampu menghasilkan senyawa metabolit yang bersifat antibakteri. Aktivitas antibakteri Rhizopus sp. ditandai dengan terbentuknya zona jernih disekitar koloni $V$. cholerae, yang menunjukkan bahwa senyawa metabolit mampu mematikan pertumbuhan $V$. cholerae.

McCue et al. (2004) melaporkan bahwa senyawa fenolik yang dihasilkan Rhizopus oligosporus NRRL 2770 pada fermentasi kedelai dapat menghambat pertumbuhan bakteri Helicobacter pylori penyebab infeksi dan kanker lambung. Kadar fenol tertinggi diperoleh setelah 6 hari fermentasi. Fadahunsi et al. (2013) melakukan penelitian fermentasi R. oligosporus NRRL 2770 pada medium Potato Dexrose Broth (PDB). Setelah 8 hari, filtrat bebas sel dari $R$. oligosporus NRRL 2770 dapat menghambat pertumbuhan bakteri gram negatif dan positif. Urutan zona penghambatan $R$. oligosporus NRRL 2770 terhadap patogen uji dalam penelitian Fadahunsi et al (2013) adalah Escherichia coli, Salmonella typhi, Pseudomonas aeruginosa, Bacillus subtilis (8 $\mathrm{mm})$, Staphylococcus aureus, Klebsiella pneumoniae, Corynebacteria diphtheriae $(7 \mathrm{~mm})$ dan Proteus mirabilis (6,5 $\mathrm{mm})$. Filtrat sebagai antibakteri optimum pada $\mathrm{pH} 4$ dan suhu $37^{\circ} \mathrm{C}$.

Hasil penelitian Sukron et al. (2014), menunjukkan bahwa filtrat $R$. oligosporus Saito dari inokulum tempe dapat menghambat pertumbuhan bakteri $E$. coli secara in vitro, sedangkan filtrat ekstrak tempe kedelai tidak 
dapat menghambat pertumbuhan bakteri. Hasil tersebut membuktikan bahwa senyawa yang bersifat antibakteri terdapat pada $R$. oligosporus Saito berpengaruh terhadap pertumbuhan $E$. coli, dengan diameter zona hambat sebesar 5,68 $\mathrm{mm}$.

Filtrat yang dihasilkan oleh Rhizopus sp.IP dan Rhizopus sp.IJ pada penelitian ini mempunyai daya antibakteri yang lebih tinggi dibandingkan hasil penelitian McCue et al. (2004) dan Sukron et al. (2014). Hal ini ditunjukkan dari diameter zona hambat Rhizopus sp.IP dan Rhizopus sp.IJ yang terbentuk $(9,25$ dan $9,38 \mathrm{~mm})$ lebih tinggi dibandingkan 2 (dua) hasil penelitian terdahulu (5-8 $\mathrm{mm}$ ). Perbedaan hasil tersebut kemungkinan dikarenakan jenis senyawa antibakteri yang dihasilkan Rhizopus berbeda-beda. Pada penelitian ini senyawa antibakteri belum diidentifikasi. Penggunaan medium fermentasi SDB belum spesifik untuk memproduksi senyawa metabolit tertentu.

Kapang Rhizopus menghasilkan senyawa metabolit yang berbeda-beda dalam pertumbuhannya. Rhizopus oryzae GY18 menghasilkan etanol, asam laktat, dan asam fumarat dalam jumlah tinggi (Guo et al., 2010). Rhizopus oryzae 15 yang tumbuhkan pada Potato Dextrose Broth (PDB), menghasilkan metil euginol yang mempunyai aktivitas antibiotik, benzena dan asam lemak (Peeran et al., 2018). Metil eugenol dari Rhizopus oryzae 6975 dapat bersifat antijamur, antibakteri dan penarik serangga (hormon seks serangga) (Faisal \& Prasad, 2016). Ekstrak etil asetat dari miselium Rhizopus stolonifer mempunyai kemampuan antibakteri terhadap Ervinia carotovora dan Xanthomonas campestris (Iqbal et al., 2014). Ekstrak dengan pelarut asetonitril dan n-heksan dari $R$. stolonifer mempunyai potensi sebagai antibakteri pada P. aeruginosa, E. coli, S. aureus, S. aureus (methicillin resistant), S. aureus (vancomycin resistant). Ekstrak asetonitril dari $R$. stolonifer lebih efektif menghambat bakteri dibandingkan ekstrak n-heksan (Sohail et al., 2014).

Fermentasi kedelai oleh Rhizopus oligosporus efektif meningkatkan kemampuan ekstrak kedelai untuk menghambat pertumbuhan Heliobacter pylori secara in vitro. Penghambatan dapat terjadi melalui penumpukan fenolik pada membran, mengganggu fungsi atau melalui gangguan transpor elektron rantai respirasi (McCue et al., 2004).

Diameter zona hambat Rhizopus sp.IP dan Rhizopus sp.IJ dalam penelitian ini lebih rendah dibandingkan tetrasiklin $30 \mu \mathrm{g}$ yang digunakan sebagai kontrol positif (Tabel 1). Berdasarkan kategori daya antibakteri, daya antibakteri Rhizopus sp.IP dan Rhizopus sp.IJ dikategorikan sedang, tetrasiklin $30 \mu \mathrm{g}$ dikategorikan sangat kuat. Menurut Davis \& Stout (1971), kategori daya antibakteri dikelompokkan berdasarkan diameter zona hambat menjadi empat kategori yaitu: lemah $(<5 \mathrm{~mm})$, sedang $(5-10 \mathrm{~mm})$, kuat $(10-20 \mathrm{~mm})$, dan sangat kuat ( $>20 \mathrm{~mm})$.

Tetrasiklin $(30 \mu \mathrm{g})$ digunakan sebagai kontrol positif mampu menghambat Vibrio cholerae dengan diameter zona hambat $21 \mathrm{~mm}$, sedangkan Rhizopus sp.IP dan IJ menghambat dengan diameter zona hambat 9,25 mm dan 9,38 mm. Berdasarkan diameter zona hambat yang terbentuk tersebut, maka $V$. cholerae bersifat sensitif terhadap tetrasiklin dan resisten terhadap Rhizopus sp.IP dan Rhizopus sp.IJ. Menurut CLSI (2002), interpretasi $V$. cholerae terhadap tetrasiklin berdasarkan diameter zona hambat dikelompokkan menjadi 3 (tiga) yaitu: susceptible atau sensitif $(\geq 19 \mathrm{~mm})$, intermediate $(15-18 \mathrm{~mm})$ dan resistent $(\leq 14$ $\mathrm{mm})$.

Hasil uji-t nilai signifikansi sebesar 0,899 ( $\mathrm{P}>0,05)$, menunjukkan bahwa daya antibakteri antara Rhizopus sp.IP dan Rhizopus sp.IJ terhadap pertumbuhan $V$. cholerae berbeda tidak nyata, sehingga dapat disimpulkan bahwa tidak ada perbedaan daya antibakteri Rhizopus sp.IP dan Rhizopus sp.IJ terhadap pertumbuhan $V$. cholerae. Uji tersebut menunjukkan bahwa adanya perbedaan spesies Rhizopus yang digunakan dalam pembuatan tempe akan menghasilkan daya antibakteri yang tidak berbeda.

Hasil penelitian uji antibakteri pada penelitian ini menunjukkan bahwa Rhizopus asal inokulum tempe mempunyai potensi menghambat pertumbuhan Vibrio cholerae 
dengan kategori penghambatan sedang. Diperlukan identifikasi dan karakterisasi senyawa antibakteri yang dihasilkan Rhizopus sp, sehingga diharapkan dapat meningkatkan daya hambatnya.

\section{Kesimpulan}

Rhizopus asal inokulum tempe komersial mampu menghambat pertumbuhan Vibrio cholerae. Kemampuan penghambatan yang teramati termasuk dalam kategori sedang. Tidak ada perbedaan daya antibakteri Rhizopus sp.IP dan Rhizopus sp.IJ terhadap Vibrio cholerae.

\section{Daftar Pustaka}

Babu, P. D., Bhakyaraj, R., \& Vidhyalakshmi, R. (2009). A Loa Cost Nutritious Food Tempe. World Journal of Diary and Food Sciences, 4(1), 22-27.

Barus, T., Maya, F., \& Hartanti, A. T. (2019). Peran Beberapa Galur Rhizopus microsporus yang Berasal dari "laru tradisional" dalam Menentukan Kualitas Tempe. Jurnal Aplikasi Teknologi Pangan, 8(1), 17-22. doi.org/10.17728/ jatp.3761

Brooks, G. F., Carroll, K. C., Butel, J. s, Morse, S. A., \& Mietzner, T. A. (2012). Jawetz, Melnick, E Adelberg Mikrobiologi Kedokteran (25th ed.; A. Adityaputri, C. Salim, F. Sandra, M. Iskandar, Nalurita, P. Ayuningtyas, S. Debby, Eds.). Jakarta: Penerbit Buku Kedokteran EGC.

CLSI. Clinical And Laboratory Standarts Institute (2002). Performance Standards for Antimicrobial Disk and Dilution Susceptibility Tests for Bacteria Isolated from Animals; Approved Standard Second Edition.

Davis, W. W., \& Stout, T. R. (1971). Disc Plate Method of Microbiological Antibiotic Assay. Applied Microbiology, 22(4), 666670. doi.org/10.1128/aem.22.4.666670.1971

Dewi, R. S., \& Aziz, S. (2011). Isolasi Rhizopus oligosporus pada Beberapa Inokulum Tempe di Kabupeten Banyumas. Molekul, 6(2), 93-104.

Fadahunsi, I. F., Ogunbanwo, S. T., \& Ogundana, D. T. (2013). Heat
Stability And Optimization Of Invitro Antimicrobial Activity Of Metabolites Produced By Rhizopus oligosporus NRRL 2710 Against Some Pathogenic Bacteria. Trakia Journal of Sciences, 11(2), 110-117.

Faisal, M. ., \& Prasad, L. (2016). A Potential Source of Methyl-Eugenol From Secondary Metabolite of Rhizopus oryzae 6975. International Journal of Applied Biology and Pharmaceutical Technology, 7(4), 187-192. doi.org/10.21276/ Ijabpt.2016.7.4.22

Fisher, F., \& Cook, N. B. (1998). Fundamentals of Diagnostic Mycology. Philadelphia: W.B. saunders.

Guo, Y., Yan, Q., Jiang, Z., Teng, C., \& Wang, X. (2010). Efficient Production of Lactic Acid from Sucrose and Corncob Hydrolysate by a Newly Isolated Rhizopus oryzae GY18. Journal of Industrial Microbiology and Biotechnology, 37(11), 1137-1143. doi.org/10.1007/ s10295-010-0761-2

Hartanti, A. T., Rahayu, G., \& Hidayat, I. (2015). Rhizopus Species from Fresh Tempeh Collected from Several Regions in Indonesia. HAYATI Journal of Biosciences, 22(3), 136-142. doi. org/10.1016/j.hjb.2015.10.004

Iqbal, M., Amin, M., Iqbal, Z., Bibi, H., Iqbal, A., Din, Z., M. Suleman., \& Shah, H. . (2014). Antimicrobial, Cytotoxic and Phytotoxic Potency of Ethyl Acetate Extract of Rhizopus stolonifer culture. Tropical Journal of Pharmaceutical Research,13(1), 87-92. doi.org/10.4314/ tjpr.v13i1.13

Karmini, M., Mahmud, E., Affandi, \& Hermana. (1987). Pengaruh tempe dalam mengurangi risiko terhadap diare akibat infeksi bakteri enteropatogen Escherichia coli. Penelitian Gizi Dan Makanan, 10, 61-76.

Kiers, J. L., Meijer, J. C., Nout, M. J. R., Rombouts, F. M., Nabuurs, M. J. A., \& Van Der Meulen, J. (2003). Effect of fermented soya beans on diarrhoea and feed efficiency in weaned piglets. Journal of Applied Microbiology, 95(3), 545-552. doi.org/10.1046/j.13652672.2003.02011.x 
Khikmah et al.

McCue, P., Lin, Y. T., Labbe, R. G., \& Shetty, K. (2004). Sprouting and solid-state bioprocessing by Rhizopus oligosporus increase the In Vitro antibacterial activity of aqueous soybean extracts against Helicobacter pylori. Food Biotechnology, 18(2), 229-249. doi. org/10.1081/FBT-200025669

Nout, M. J. R., \& Kiers, J. L. (2005). Tempe fermentation, innovation and functionality: Update into the third millenium. Journal of Applied Microbiology, 98(4), 789-805. doi. org/10.1111/j.1365-2672.2004.02471.x

Peeran, M., Prasad, L., \& Kamil, D. (2018). Characterization of Secondary Metabolites from Rhizopus oryzae and Its Effect on Plant Pathogens. International Journal of Current Microbiology and Applied Sciences, 7(03), 705-710. doi. org/10.20546/ijcmas.2018.703.082

Purwijantiningsih, E., Dewanti-hariyadi, R., Nurwitri, C. C., \& Istiana (alm.). (2005). Penghambatan Produksi Aflatoksin dari Aspergillus flavus oleh Kapang dan Khamir yang Diisolasi dari Ragi Tempe. Biota, X(3), 146-153.

Puspandari, N., Sariadji, K., \& Wati, M. (2009). Identifikasi Penyebab Kejadian Luar Biasa Kolera Di Papua Terkait Kontak Jenazah dan Sanitasi. Widyariset, 13(2), 69-74.

Samson, R. A., Hoekstra, E. S., \& Frisvad, J. C. (2004). Introduction To Food And AirBorne Fungi (7th ed.). Netherlands: CBS.

Sariadji, K. (2019). Benarkah tak ada kasus kolera di Indonesia atau tersamarkan dengan sebutan diare? The Conversation, pp. 2-6. Retrieved from https:// theconversation.com/benarkahtak-ada-kasus-kolera-di-indonesiaatau-tersamarkan-dengan-sebutandiare-110576

Sohail, Afzal, M., Iqbal, Z., Sheena, Khan, S. ., Rahman, U., Khan, W., Asghar, A., Ullah, I., \& Numan, M. (2014). Antimicrobial Activity of Mycelial Extracts of Rhizopus stolonifer against Different Fungal and Bacterial Pathogenic Strains. International Journal
Sciscitatio, Vol. 2, No. 2, Juli 2021

of Biosciences (IJB), 4(7), 276-282. doi. org/10.12692/ijb/4.7.276-282

Sukron, M. A., Suarsini, E., \& Witjoro, A. (2014). Pengaruh Ekstrak Tempe Kedelai (Glycine max (L) Merr.) dan Ekstrak Inokulum Kapang Tempe Terhadap Penghambat Esherichia coli Secara in Vitro. Universitas Negeri Malang, Malang. 